\title{
Ecology and behaviour of avian diversity in Nallamala forest region, Kurnool district, Andhra Pradesh
}

M. Nagabhushan Reddy, C. Vijaya Lakshmi, G. Narasimha, B. Nagarjuna, K. Pavan Kumar and Md Basha Mohideen

Article Chronicle :

Received:

15.03.2018;

Revised :

20.03.2018;

Accepted :

26.03.2018

Key Words :

Aves, Biodiversity,

Behaviour,

Nallamala forest,

Kurnool
ABSTRACT : Biodiversity is the variety among the living organisms, biological systems and biological processes found on earth. India contains about 8 per cent of the world's biodiversity on 2 per cent of the Earth's surface, making it one of the 12 mega diversity countries in the world. Acquiring knowledge of flora and fauna is of immense scientific and commercial importance. Nallamala Hills stretching across five districts across portions of Kurnool, Prakasam, Nalgonda, Guntur and Kadapa of the state of Andhra Pradesh is renowned for being rich in biodiversity. Nallamala $\left(15^{\circ} 20^{\prime}-16^{0} 31^{\prime} \mathrm{N}\right.$ and $78^{0} 30^{\prime}-$ $80^{\circ} 10^{\prime} \mathrm{E}$ ) is a group of low hill ranges in the central part of Eastern Ghats. The vegetation is typically of southern tropical dry deciduous and southern tropical moist deciduous forest types intermingled with shrub. The climate is generally hot and dry with temperatures rising upto $43^{\circ} \mathrm{C}$ to $45^{\circ} \mathrm{C}$ during May and dips down to $8^{\circ} \mathrm{C}$ in December. Average rainfall in this region is between 900 and $1000 \mathrm{~mm}$. Though several research activities and surveys were made or undergoing in the area of study / project i.e. Nallamala forest (Kurnool region), Andhra Pradesh regarding the characterization, quantification of the species diversity, very little is known to public and which are confined to research area people only. Ecology and behaviour of the species diversity especially in relation to aves gives the impressive knowledge on the species diversity for the public / students even from the College / University level.

HOW TO CITE THIS ARTICLE : Nagabhushan Reddy, M., Vijaya Lakshmi, C., Narasimha, G., Nagarjuna, B., Pavan Kumar, K. and Basha Mohideen, Md (2018). Ecology and behaviour of avian diversity in Nallamala forest region, Kurnool district, Andhra Pradesh. Asian J. Environ. Sci., 13(1\&2): 1-7, DOI: 10.15740/HAS/ AJES/13.1and2/1-7. Copyright@ 2018: Hind Agri-Horticultural Society.

Author for correspondence : 